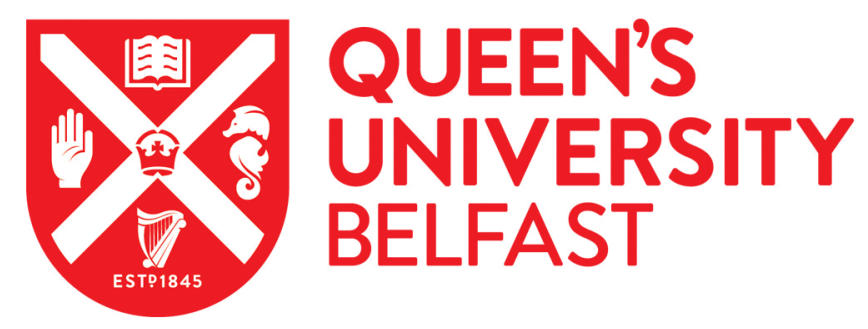

\title{
The Truth about Loyalty: Emotions, Ex-Combatants and Transitioning from the Past.
}

Lawther, C. (2017). The Truth about Loyalty: Emotions, Ex-Combatants and Transitioning from the Past. International Journal of Transitional Justice, 11(3), 484-504. [11, 3]. https://doi.org/10.1093/ijt/ijx019

Published in:

International Journal of Transitional Justice

Document Version:

Peer reviewed version

Queen's University Belfast - Research Portal:

Link to publication record in Queen's University Belfast Research Portal

Publisher rights

( 2017 OUP. This work is made available online in accordance with the publisher's policies. Please refer to any applicable terms of use of the publisher.

\section{General rights}

Copyright for the publications made accessible via the Queen's University Belfast Research Portal is retained by the author(s) and / or other copyright owners and it is a condition of accessing these publications that users recognise and abide by the legal requirements associated with these rights.

Take down policy

The Research Portal is Queen's institutional repository that provides access to Queen's research output. Every effort has been made to ensure that content in the Research Portal does not infringe any person's rights, or applicable UK laws. If you discover content in the Research Portal that you believe breaches copyright or violates any law, please contact openaccess@qub.ac.uk. 


\title{
The Truth about Loyalty: Emotions, Ex-Combatants and Transitioning from the Past
}

\begin{abstract}
Despite a rich body of literature on ex-combatants in transitional contexts, the reasons why former armed actors may be reluctant to engage with formal mechanisms of truth recovery have been less well explored. This article argues that ex-combatants' antipathy towards truth recovery cannot be properly understood without a critical interrogation of the emotions vested in the combatant-ex-combatant experience and the intersection between emotions, politics and ideology. In particular, the paper focuses on the emotion of loyalty and its influence on pro-state armed actors. It uses the case of loyalist ex-combatants in Northern Ireland as a prism through which to explore this tension. Four overlapping notions of loyalty are identified - 'Loyalty as Betrayal', 'Loyalty, Blame and Managing Shame', 'Loyalty as Silence' and 'Loyalty as Protection'. The paper concludes by suggesting the need for greater recognition of the role of loyalty in mediating relationships with and willingness to investigate the past.
\end{abstract}

Key words: ex-combatants, truth recovery, loyalty, emotions, pro-state armed groups.

\section{Introduction}

As transitional justice has evolved and matured from the early 'truth versus justice' debate, more nuanced discussions around the role and place of ex-combatants in transitional contexts have taken place. Those discussions include the challenges associated with Disarmament, Demobilisation and Reintegration (DDR) schemes, the complexity of the victim-perpetrator axis, the involvement of former armed actors in grassroots conflict transformation and peacebuilding initiatives and the potential benefits of ex-combatants' participation truth recovery. Beyond framing past actions in a context of denial or silence or claims of heroism, fiction, lies and amnesia, less well explored are ex-combatants' objections to engaging with formal mechanisms of truth recovery. ${ }^{1}$ This article seeks to extend this discussion by arguing that ex-combatants' antipathy towards truth recovery cannot be properly understood without a critical interrogation of the emotions vested in the combatant-ex-combatant experience and the intersection between emotions, politics and ideology. In particular, I am interested in the emotion of loyalty and its influence on pro-state armed actors. To explore this further, this article uses the case of loyalist ex-combatants in Northern Ireland as a prism through which to examine the impact of loyalty on former pro-state actors opposition to truth recovery.

There are three specific yet overlapping reasons for this empirical and theoretical focus. First, as de Brito et $\mathrm{al}^{2}$ note, for those who are loyal to the pre-transitional regime, truth and justice policies are particularly challenging because they not only attack the raison d'etre or the legitimacy of that regime, but provoke powerful emotional reactions in those who have inflicted and endured violence as an expression of their loyalty to the previous regime, through, for example, interrogating their actions in defence of the state and the state's response or rejection of their commitment and sacrifice. Second, and explored in further detail below, in contrast to forgiveness, guilt or resentment for example, loyalty is an emotion that has been largely to the sidelines in contemporary discussions of transitional justice.

\footnotetext{
${ }^{1}$ Stan Cohen, States of Denial (Cambridge: Polity Press, 2001); Leigh Payne, Unsettling Accounts: Neither Truth nor Reconciliation in Confessions of State Violence (Durham: Duke University Press, 2008).

${ }^{2}$ Alexandra De Brito, Carmen Gonzalez-Enriquez and Paloma Aguilar, The Politics of Memory:

Transitional Justice in Democratizing Societies (Oxford: Oxford University Press, 2001).
} 
Loyalty is a marker of identity, a signifier of community and a guide to action. ${ }^{3}$ Taken to its extreme, while loyalty can inspire devotion, commitment and sacrifice, it can also provide the motivation and justification for violent and deadly acts. ${ }^{4}$ Moreover, loyalty does not die or is not ameliorated by peace agreements and the cessation of hostilities. Rather, where loss, trauma and belonging are discussed post-conflict, the tension between loyalty to the past (to lost ideals, victims and comrades) and to the future (to the realization of a particular way of life and the development of one's community) will be acute. To fail to appreciate the emotional importance of loyalty in transitional justice, and in particular, in respect to pro-state combatants is therefore remiss.

Thirdly, the case study of loyalist ex-combatants in Northern Ireland - former paramilitary associates of the Ulster Volunteer Force (UVF) and the Ulster Defence Association (UDA) is one that is timely and theoretically rich. At the time of writing, Northern Ireland's leading political parties are engaged in negotiations on, amongst other issues, how best to deal with the legacy of the past. Loyalist ex-combatants have considerable concerns about the establishment of or need to participate in a formal truth process. ${ }^{5}$ However, in the main, their views on truth recovery have been at the margins of debate and have been an unexplored area of scholarly analysis. ${ }^{6}$ Yet, they are a constituency with significant truths to contribute and uncover by engaging with the past - both concerning their own involvement in conflict and wider structural and political dynamics. Moreover, if Northern Ireland is to truly 'deal with' its past, loyalist ex-combatants must be represented in the design and delivery of past facing mechanisms. A critical exploration of their objections is therefore pertinent in both scholarly and practical terms.

The structure of the paper as is follows. The paper begins by setting out the existing literature on emotions and transitional justice and draws attention to the absence of loyalty within this field. A definition of loyalist ex-combatants and their pro-state status follows. The third section of the paper guides readers to the debate on dealing with the past in Northern Ireland. The fourth part of the paper discusses the methodological approach and the means of analysis. Drawing on interview material, I will then argue that four overlapping notions of loyalty map directly onto contested understandings of the past and loyalists' attitudes to truth recovery. They are 'Loyalty as Betrayal', 'Loyalty, Blame and Managing Shame', 'Loyalty as Silence' and 'Loyalty as Protection'. Each is explored in turn. The conclusion argues for greater recognition of the role of loyalty in mediating relationships with and willingness to investigate the past.

\section{Loyalty and the Emotions of Peace and Conflict}

According to Hutchinson and Bleiker ${ }^{7}$, emotions help us make sense of our self and situate us in relation to others and the world that surrounds us. While the emotions and transitional justice is a developing area of scholarship, a number of distinct areas of investigation can be

\footnotetext{
${ }^{3}$ James Connor, The Sociology of Loyalty (New York: Springer, 2007).

${ }^{4}$ Martha Nussbaum, Hiding from Humanity: Disgust, Shame and the Law (Princeton, New Jersey: Princeton University Press, 2004).

${ }^{5}$ Ex-Prisoners Interpretive Centre, Truth Recovery: A Contribution from within Loyalism (Belfast: ExPrisoners Interpretive Centre, 2004); Ex-Prisoners Interpretive Centre, Truth Recovery Revisited: A Contribution from within Loyalism (Belfast: Ex-Prisoners Interpretive Centre, 2014).

${ }^{6}$ Combined Loyalist Military Command Ceasefire Statement, 13 October 1994. Available at: http://cain.ulst.ac.uk/events/peace/docs/clmc131094.htm (accessed on 8 October 2016); Bill Rolston, 'Dealing with the Past: Pro-State Paramilitaries, Truth and Transition in Northern Ireland', Human Rights Quarterly 28(3) (2006): 652-675; Ex-Prisoners Interpretive Centre 2004 and 2014, supra n 5. ${ }^{7}$ Emma Hutchinson and Roland Bleiker, 'Emotional Reconciliation: Reconstituting Identity and Community After Trauma', European Journal of Social Theory 11(3) (2008): 385-403.
} 
identified. ${ }^{8}$ The first concerns drawing attention to the longevity of emotions particularly where there is communication among the victims of the wrongdoing or where codes of honour keep memories alive - both vital factors for those planning the design and implementation of mechanisms of transitional justice. ${ }^{9}$ Second is scholarship on specific emotions and their role in transitional periods. Much of this literature concentrates on what are traditionally defined as 'positive' or 'negative' emotions - the role of forgiveness or fear, guilt or shame for example. ${ }^{10}$ Emerging alongside is Brewer's recent work on the need to elevate 'future-focused' emotions like hope, empathy and compassion above 'past-focused' emotions such as mistrust, fear and revenge in public debates about dealing with the legacy of violent conflict. ${ }^{11}$ Third is literature which focuses on emotions, emotion management and specific mechanisms of transitional justice. This includes, for example, Braithwaite's ${ }^{12}$ work on re-integrative shaming, Wilson's ${ }^{13}$ critique of the South African Truth and Reconciliation Commission's overwhelming emphasis on forgiveness, Muldoon's ${ }^{14}$ call to carve out a space in which to recognise the moral legitimacy of victims' anger, Doak's ${ }^{15}$ work on emotional repair and victim satisfaction in international trials and truth commissions and Karstedt's ${ }^{16}$ framework of 'emotion sharing' in transitional justice settings.

Missing from this field is a thoroughgoing analysis of the emotion of loyalty and how actors' loyalty to the past, the present and the future shapes their attitudes to transitional justice and in specific, participation in truth recovery. Loyalty is an emotion which inspires and calls for devotion, commitment and sacrifice and according to Shklar ${ }^{17}$, it is 'deeply affective and not primarily rational. ...It is all of one that tends to be loyal'. Shaped through shared experiences, collective memories, language, traditions and sentiments, loyalty is a socially constructed and performative behavior. ${ }^{18}$ It signifies membership and a sense of belonging to a distinctive group, and provides justification for action and behavior (although as explored below, we can act in ways contrary to how we feel and raw feelings need not be enacted in behavior). ${ }^{19}$ On this basis, Flam ${ }^{20}$ defines loyalty as a 'cementing emotion' that generates and upholds commitment to social structures and binds members of society to the prevailing

\footnotetext{
${ }^{8}$ For a comprehensive overview, see: Emma Hutchinson, Affective Communities in World Politics: Collective Emotions after Trauma (Cambridge: Cambridge University Press, 2016).

${ }^{9}$ Jon Elster, Closing the Books: Transitional Justice in Historical Perspective (Cambridge: Cambridge University Press, 2004).

${ }^{10}$ Desmond Tutu, No Future without Forgiveness (London: Rider, 2000); Thomas Scheff, Bloody Revenge (Boulder: Westview, 1994); Daniel Bar-Tal, Eran Halperin and Joseph de Rivera, 'Collective Emotions in Conflict Situations: Societal Implications', Journal of Social Issues 63(2) (2007): 441-460; Thomas Brudholm, Resentment's Virtue: Jean Amery and the Refusal to Forgive (Philadelphia: Temple University Press, 2010); Michaela Mihai, Negative Emotions and Transitional Justice (New York: Columbia University Press, 2016).

${ }^{11}$ John Brewer, 'Guilt, anger and forgiveness as issues in transitional justice', paper presented at the Institute of Advanced Study, Warwick University, 4 March 2016. Copy on file with author.

12 John Braithwaite, 'Repentance Rituals and Restorative Justice', The Journal of Political Philosophy 8(1) (2000): 118 .

${ }^{13}$ Richard Wilson, The Politics of Truth and Reconciliation in South Africa: Legitimizing the PostApartheid State (Cambridge: Cambridge University Press, 2001).

${ }^{14}$ Paul Muldoon, 'The Moral Legitimacy of Anger', European Journal of Social Theory 11(3) (2008): 299-314.

${ }^{15}$ Jonathan Doak, 'The Therapeutic Dimension of Transitional Justice: Emotional Repair and Victim Satisfaction in International Trials and Truth Commissions', International Criminal Law Review 11(2) (2011): 263-298.

${ }^{16}$ Suzanne Karstedt, 'The Emotion Dynamics of Transitional Justice: An Emotion Sharing Perspective', Emotion Review 8(1) (2016): 50-55.

${ }^{17}$ Judith Shklar, 'Obligation, Loyalty, Exile', Political Theory 21(2) (1993): 184.

${ }^{18}$ Jack Katz, How Emotions Work (Chicago: University of Chicago Press, 1999).

${ }^{19}$ Connor, supra $\mathrm{n} 3$.

${ }^{20}$ Helena Flam, "Introduction" in Emotions and Social Movements, eds Helena Flam and Debra King (Abingdon: Routledge, 2005), 1-18.
} 
order. Loyalty may therefore be thought of as a prism through which other emotions such as joy, forgiveness, anger or revenge are mediated and is essential to understanding their expression. This is particularly true in the context of conflict and transition when loyalty is a marker of in-group or out-group status and provides a guide to behavior during conflict and the reception of peace processes and transitional mechanisms. ${ }^{21}$ For pro-state combatants who by definition are 'loyal' and have engaged in conflict on that basis, understanding the meaning of their loyalty and the challenges it poses in times of transition and re-examination of the past is therefore particularly pressing. This paper contributes to filling that gap.

\section{Explaining Loyalism}

Focusing on loyalist ex-combatants in Northern Ireland, this paper adopts the definition that 'Loyalists are understood as those who have been involved in paramilitarism and/or Loyalistinspired political and community-centred activity'. ${ }^{22}$ This is distinct from the idea of loyalism as a broader political perspective, the exploration of which is beyond the scope of this paper. A demarcation can also be drawn between loyalism and unionism - which, while sharing loyalists' commitment to Northern Ireland and the maintenance of the union with Great Britain, has historically been associated with middle-class politics, a commitment to law and order and a close relationship with the security forces. ${ }^{23}$ The pro-state designation has been used to capture loyalists' loyalty to the state and their willingness to use illegal violence to protect the state against the threat of violent republicanism (as opposed to anti-state forces who were willing to use illegal violence to destroy or radically change the state) ${ }^{24}$ It has also been used to clarify that the focus of this paper is on the relationship between loyalist excombatants, the emotion of loyalty and how this pro-state stance has impacted on their attitudes to truth recovery. It is not the intention of this paper to consider, as others have done, whether loyalist ex-combatants are, for example, revanchist or progressive forces in the post-conflict period. ${ }^{25}$

Although the histories, tactics and leadership values of the two main loyalist paramilitary groups the Ulster Defence Association (UDA) and the Ulster Volunteer Force (UVF) differed, traditionally, loyalists have expressed loyalty to the British Crown and flag and a strong feeling of 'belonging' to the imagined political community of Ulster. Constituted as rational, irreproachable and intuitively natural, loyalists' loyalty is offset by the construction of the 'disloyal' 'Other' - those nationalists and republicans who challenged the legitimacy of the Northern Ireland state. ${ }^{26}$ Their conflict was therefore one of defence and their 'crimes' were those of 'loyalty'. ${ }^{27}$ In total, loyalist paramilitaries were responsible for 996 deaths including 54 nationalist or republican activists and 712 Catholic civilians. ${ }^{28}$ In October 1994, under the auspices of Combined Loyalist Military Command (CLMC), the UVF and UDA publicly announced their cessation from violence. Despite sporadic violence and intraloyalist feuding, the ceasefire has continued to hold and, in both personal and structural terms,

\footnotetext{
${ }^{21}$ Albert Hirschman, Exit, Voice and Loyalty: Responses in Decline in Firms, Organizations and States (London: Oxford University Press, 1970).

${ }^{22}$ Pete Shirlow, The End of Ulster Loyalism? (Manchester: Manchester University Press, 2012), 8.

${ }^{23}$ For a fuller introduction to unionism see: James McAuley, Ulster's last stand? Reconstructing unionism after the peace process (Dublin: Irish Academic Press, 2010).

${ }^{24}$ Steve Bruce, 'The problems of 'pro-state' terrorism: Loyalist paramilitaries in Northern Ireland,' Terrorism and Political Violence 4(1): 67-88.

${ }^{25}$ See for example: Carolyn Gallagher, After the Peace: Loyalist paramilitaries in post-accord Northern Ireland (Ithaca: Cornell University Press, 2007); Shirlow, supra n 22.

${ }^{26}$ McAuley, 2010, supra $n 23$.

${ }^{27}$ Ian Wood, Crimes of Loyalty. A History of the UDA (Edinburgh: Edinburgh University Press ltd, 2006).

${ }^{28}$ Shirlow, supra n 22.
} 
there is evidence of former combatants working to decrease remaining political and social tensions. $^{29}$

\section{Methodology}

This paper is based on an entirely qualitative research methodology and draws on two phases of field research completed in 2009 and 2015 with former members of the UVF and UDA. This research was part of a broader project on unionists', loyalists' and the security forces' attitudes to the establishment of a formal truth process in Northern Ireland. ${ }^{30}$ Over 50 semistructured interviews were completed and the timing of the fieldwork allowed the author to capture loyalist ex-combatants' voices at crucial junctures in the debate on dealing with the past - following the publication of the Report of the Consultative Group on the Past in 2009 and the Stormont House Agreement in 2014 - both of which have been a decisive influence on the design and structure of potential legacy mechanisms. Semi-structured interviews were chosen for their capacity to encourage participants to 'ramble' in their responses and offer feedback within their own frames of reference, combining structure with flexibility. ${ }^{31}$ Responses were therefore highly individual and provided a detailed insight into how participants' experience of conflict (including prison time), peace and involvement in community work has shaped and refined their perspectives on legacy issues. This undoubtedly contributed to the quality and richness of the data collected. ${ }^{32}$ Moreover, having the flexibility to raise questions not previously formulated, I was able to enter into a process of dialogue and exchange with participants, facilitating clarification and elaboration of key areas or current issues. Structured or unstructured interviews would not have provided these benefits. Equally, given the sensitivities of the research matter and ongoing tensions between the different branches of the UDA and between the UDA and UVF, focus groups would not have been a suitable research method.

Prior to commencing the fieldwork, an interview schedule was developed. Questions were organized thematically and informed by both the literature on ex-combatants and transitional justice and that on loyalist ex-combatants, their experiences during the conflict and peace process and their attitudes to existing and prospective mechanisms of truth recovery. Over the course of the research the interview schedule was adapted to accommodate the changing political landscape in Northern Ireland and progress (or not) on legacy issues. Institutional ethical approval was granted at both stages of the research in 2009 and $2015 .{ }^{33}$ A purposeful sampling methodology was employed and interviewees approached on the basis of their relevance to the research questions. Selection criteria included association with the UDA or UVF, knowledge and experience of the debate on dealing with the past and involvement in conflict transformation work. Several individual's subsequently acted as gatekeepers and facilitated access to other interviewees. All respondents were male and based in the Belfast or Greater Belfast area. The choice to conduct the fieldwork in the Belfast and Greater Belfast area was one of practicality. The Belfast area is where a considerable number of loyalist excombatants are based and where there is a concentration of ex-prisoner organisations and community and voluntary groups staffed by former loyalist combatants. This geographical area also covers some of the electoral wards where conflict was most acute and where socio-

\footnotetext{
${ }^{29}$ James McAuley, Jon Tonge and Pete Shirlow, 'Conflict, Transformation, and Former Loyalist Paramilitary Prisoners in Northern Ireland,' Terrorism and Political Violence 22(1) (2009): 22-40.

${ }^{30}$ Some of the ideas in this paper have also emerged from an ongoing research project entitled XXX

${ }^{31}$ Alan Bryman, Social Research Methods, $2^{\text {nd }}$ ed (Oxford: Oxford University Press, 2004) 320.

${ }^{32}$ Tim May, Social Research. Issues, methods and process, $3^{\text {rd }}$ ed (Berkshire: Open University Press, 2001).

${ }^{33}$ Queen's University Belfast has rigorous ethical policies and has incorporated the Concordat to Support Research Integrity. Full details can be found at: http://www.qub.ac.uk/directorates/ResearchEnterprise/ResearchGovernanceandEthics (accessed on 30 March 2017).
} 
economic deprivation is most pronounced. Interviews lasted approximately 90 minutes and in the interests of researcher safety, all interviews took place in community centres or voluntary organisations where participants were based. With the permission of each interviewee, interviews were audio recorded and then transcribed in full by the author.

Once transcribed, the data was thematically coded and analyzed using Nvivo software. An inductive approach ${ }^{34}$ was adopted and a thematic codebook developed containing over 20 distinct codes. For the purposes of this paper, these codes were examined in light of exploring loyalist ex-combatants' attitudes to dealing with the past and how emotions, specifically loyalty have informed their views. The resulting themes were of betrayal, shame, the notion of loyalty as silence and the potential for retraumatisation as a result of re-opening the past. These themes subsequently formed the structure of this paper. Excerpts from the interviews are presented below and are supported by the relevant literature.

\section{Truth, Transition and Dealing with the Past in Northern Ireland}

The Northern Ireland conflict resulted in more than 3,700 deaths, over 40,000 injured and a legacy that includes socio-economic deprivation, prescription rates for anti-depressants that are amongst the highest in the world and an increasing prevalence of trans-generational trauma. Recent research by the Commission for Victims and Survivors Northern Ireland ${ }^{35}$ reports that over one third of Northern Ireland's population could be legally classified as a victim or survivor of the conflict. While considerable energy has been invested in, for example, the reform of policing and criminal justice and the decommissioning and demobilization of paramilitary organisations, Northern Ireland has lacked a single comprehensive approach to dealing with the past. Largely because the negotiators felt that it would have made a deal impossible, there was a broad consensus that the peace deal signed in 1998, the Belfast Agreement, would not make reference to the need to establish a formal truth recovery process ${ }^{36}$ In this vacuum, an array of truth-finding efforts have emerged, including public inquiries - such as the Saville Inquiry into the events of Bloody Sunday 30 January 1972 when British army paratroopers unlawfully killed 13 unarmed civilians, 'right to life' challenges under Article 2 of the European Convention on Human Rights, police led truth recovery by the Office of the Police Ombudsman for Northern Ireland (OPONI) which investigates historical allegations of police malpractice and the Legacy Investigation Branch (LIB) based within the Police Service of Northern Ireland (PSNI) and responsible for a coldcase review of all outstanding conflict related deaths and victim led and civil society sponsored initiatives around, for example, local storytelling and community based commemoration. Largely a 'criminal justice' response to a transitional context, this approach to the past has been uneven, incomplete and compromised by the weaknesses of the individual mechanisms. In response have been consistent calls for a full examination of the past.

The latest iteration of this debate can be found in the Stormont House Agreement (SHA), signed in December 2014 by a majority of Northern Ireland's main political parties and the British and Irish governments. Aimed at resolving the outstanding issues of the peace process, its recommendations on the past are four fold. One, a Historical Investigations Unit (HIU) - 'an independent body to take forward investigations into outstanding Troubles-related deaths'. Two, an Independent Commission on Information Retrieval (ICIR) 'to enable victims and survivors to seek and privately receive information about the deaths of their next

\footnotetext{
${ }^{34}$ May, supra n 32.

${ }^{35}$ Commission for Victims and Survivors Northern Ireland, Troubled consequence: A report on the mental health impact of the civil conflict in Northern Ireland (Belfast: Commission for Victims and Survivors Northern Ireland, 2011).

${ }^{36}$ Christine Bell, 'Dealing with the Past in Northern Ireland', Fordham International Law Journal 26(4) (2003): 1095-1147.
} 
of kin'. Three, an Oral History Archive (OHA) 'to provide a central place for people from all backgrounds to share experiences and narratives related to the Troubles'. Four, an Implementation and Reconciliation Group (IRG) 'to oversee themes, archives and information recovery ${ }^{37}$ These bodies effectively amount to a 'truth commission' designed to unpack, discharge and begin to heal the wounds of Northern Ireland's complex past. At the time of writing, progress on implementation has been painfully slow. If agreement can be reached, particularly around the British state's unwillingness to disclose sensitive 'national security' related information to families affected by the conflict, the government has indicated that the relevant bill will be introduced in Westminster in the spring of 2017 with the mechanisms 'going live' in early 2018. As this paper will argue, loyalist ex-combatants remain ill at ease with much of the direction of the current debate.

\section{Loyalty as Betrayal: From Crimes of Loyalty to Peace and Loss}

One of the defining characteristics of historical and contemporary loyalism is a fear of betrayal. In her sociological examination of betrayal, Akerstrom ${ }^{38}$ defines betrayal as a breach of trust, a breaking of a social bond and has linked it to feelings of indignation, contempt and revenge. A common refrain amongst loyalists in Northern Ireland is 'Our crime was loyalty. For we were always loyal and we got nothing. ${ }^{39}$ This statement refers to loyalists' sense of identity, their commitment to the British state - often expressed in life or death terms during the conflict and the perception that loyalists have not benefitted from the peace dividend. Included within this critique are the claims that while the anticipated return on their sacrifice was commitment and protection, loyalists have not benefitted socially or culturally in the post-Agreement period, that they have failed to improve their increasingly marginalised economic position and that they have lost out to republican demands and organisation in the political arena - or what one interviewee termed 'the front onslaught of Irish republicanism and the rear assault of duplicity from the British government'. ${ }^{40}$ For loyalists, and in Akerstrom's ${ }^{41}$ terms, the peace process has been characterised by 'Not honouring the We' - the perception that their sense of individual and collective self has been undermined, that the rituals of loyalty and its markers of insider/outsider status have been disregarded and that the (imagined) reciprocal bond with the British state has been subverted. As an emotion that is linked to one's sense of identity and is created and performed in interaction with others, loyalty, when subject to emotional challenge and upset, may be particularly susceptible to its negative counterpart of betrayal. For loyalists, this tension is acute and enduring.

This backdrop has informed a key oppositional narrative in loyalist discourse on truth recovery - the argument that the British government has and will continue to prioritize republican's demands for truth concerning state abuses while loyalist truth will remain hidden, poorly articulated or understood, or deliberately misrepresented. For many loyalists, this is typified by the fact that the British government has supported a documentary review into the murder of Pat Finucane and public inquiries into the deaths of Robert Hamill and Rosemary Nelson - all members of the nationalist / republican community and whose deaths have been linked to allegations of British security force collusion with loyalist paramilitaries. Given that loyalists have historically prided themselves on the expectation that the state will

\footnotetext{
${ }^{37}$ Northern Ireland Office, The Stormont House Agreement, 23 December 2014. Available at: https://www.gov.uk/government/uploads/system/uploads/attachment data/file/390672/Stormont Hous e Agreement.pdf (accessed on 2 October 2016).

${ }^{38}$ Malin Akerstrom, Betrayal and Betrayers. The Sociology of Treachery (London: Transaction Publishers, 1991).

${ }^{39}$ McAuley, supra n 23 at 40.

${ }^{40}$ See for example: James McAuley, Very British Rebels? The Culture and Politics of Ulster Loyalism (London: Bloomsbury Academic, 2015); personal interview, UDA, 11 June 2009.

${ }^{41}$ Akerstrom, supra n 38 at 7.
} 
look after its loyal citizens, their sense of abandonment by the British state and betrayal of their sacrifice can be keenly felt -

There is a mural on the Shankill Road about the McArdles bar, Fridells fish shop, the Balmoral showrooms, the Mountain View Tavern and the Four Step Inn and it says on it 'where are our inquiries?' That is the way people feel. A republican was killed at three o'clock in the morning going for a bottle of milk, don't know where he was going to find a shop open at three o'clock in the morning to get a bottle of milk but there was an inquiry into it. But you can bomb a bar on the Shankill Road and kill 10 people and nobody gets an inquiry into that. ${ }^{42}$

Two public inquiries have however been held into issues which, at first glance, one would have thought of significance to this constituency. First is the inquiry into the death of Billy Wright, a former leading loyalist who was killed in 1997 by the republican paramilitary group the Irish National Liberation Army while in the high security Maze prison. Second is the Smithwick Inquiry which investigated the allegation that members of An Garda Siochana or other employees of the Irish state colluded in the fatal shootings of RUC Chief Superintendent Harry Breen and RUC Superintendent Robert Buchanan on 20 March 1989. However, neither of these inquiries have assuaged loyalists' concerns that truth recovery has been imbalanced. Rather, during interview, the Smithwick Inquiry was brushed aside as not being of interest, while the Wright inquiry was deemed a cynical attempt to "balance the books' vis-a-vi the number of inquiries into issues of significance for the republican community - 'I think it is a sop to be honest with you' ${ }^{43}$ In effect, for many of the loyalists I interviewed, these inquiries were seen as token gestures to placate unionists and loyalists while the state got on with the 'serious' business of republican and nationalist facing truth recovery, itself emblematic of a broader surrender to the nationalist political project. A former UDA associated interviewee well captured this point - 'it reinforces the fear and siege mentality in my community of thinking these people just won't stop, they are doing this because they want a united Ireland and it is a down ward cycle for my community'. ${ }^{44}$

Ben-Yehuda ${ }^{45}$ argues that the study of loyalty and betrayal brings one into contact with issues of power and social and moral boundaries. For loyalists, as pro-state activists, the fact that multiple high profile public inquiries into their issues of concern - specifically those cases where republican paramilitaries have been responsible for the deaths of members of the loyalist community - have not been forthcoming breaches their moral boundaries of right and wrong and equates to a betrayal of their sacrifice. Through the British states exercise of power and choice regarding historical investigations, it also violates loyalist's sense of imagined community and imagined reciprocal relationship with the state. Moreover, Shackelford and Buss ${ }^{46}$ make the point that the experience of betrayal is not isolated to one moment in time but also shapes readings of the future. Loyalists consequently believe that a formal truth process, such as that contained in the SHA would continue to marginalize their concerns. It should also be noted that unlike the negotiations leading up to the Belfast Agreement, loyalists were not involved in the design of the SHA and have little faith in the capacity of Unionist political elites to represent their interests. Indeed, one participant hinted that had loyalists been involved in the negotiations, it may have been possible to generate a more favourable outcome for this part of the community -

\footnotetext{
${ }^{42}$ Personal interview, UDA (B), 18 June 2009.

${ }^{43}$ Ibid.

${ }^{44}$ Personal interview, UDA, 11 June 2009.

${ }^{45}$ Nachman Ben-Yehuda, Betrayals and Treason. Violations of Trust and Loyalty (Cambridge, MA: Westview Press, 2001).

${ }^{46}$ Todd Shackleford and David Buss, 'Betrayal in mateships, friendships and coalitions', Personality and Social Psychology Bulletin 22(11) (1996): 1151-1164.
} 
...I haven't been allowed to talk to politicians to have an input into that. It might have been a lot different if people were allowed, if people were allowed to submit 4 pages on it - 'what's your policy on the past', 'what's your policy on victims'. If we had been brought in and sat there and been able to discuss that, I think the Stormont House Agreement might have actually opened up into a lot better than what it is. And, I also believe that Sinn Fein might have allowed it. The unionist politicians stopped it. What happens is they come up to you and talk to you about your past and your past experience in practice, but 'see after I've listened to you, you go back down there and I go back up here'. ${ }^{47}$

For loyalists, betrayal is also closely linked to the experience of anxiety - specifically over their relationship to the state and the perceived implications as regards truth recovery. Kemper $^{48}$ notes that anxiety is a sign of insufficient power and status, signaling both actor unease over the authority of a specific action, and more generally over the claim to be recognized as an authoritative actor. The lingering prospect of criminal prosecution and the perceived lack of support on the part of the state is a considerable source of anxiety for loyalists and speaks to the concern that their 'crimes of loyalty' and efforts on behalf of the state have offered little by way of commitment and protection. While largely a matter of perception, for a significant number of interviewees, the Historical Enquiries Team, the independent police body tasked with re-examining 3268 deaths attributable to the conflict between 1968 and 1998 (now replaced by the Legacy Investigations Branch within the PSNI) has been indicative of what they believe to be a biased and partial approach to the past. Loyalists have, for example, described the HET as part of the 'witch-hunt against loyalism' 'There is [sic] only 1 or 2 people who have been investigated by the HET from mainstream republicanism. ...The HET is one of the major obstacles to entering into a process. ...the HET is set up for state forces and loyalists'. ${ }^{49}$ It is true that one of the unit's most significant cases, tied to the 'Operation Ballast' investigation of a UVF gang in North Belfast resulted in the arrest of 65 loyalists. However, at the close of the HET's work in December 2014, the actual number of cases referred to the PSNI's criminal investigations branch was $104-69$ of which were attributed to republicans and 35 to loyalists. ${ }^{50}$ Across all legacy mechanisms, two loyalists and two republicans have been convicted of pre-1998 conflict related murders or attempted murders. ${ }^{51}$ There is therefore a considerable disjuncture between loyalists' interpretation of the HET and other legacy mechanisms and the reality of post-conflict criminal investigations. The key to understanding loyalists sense of a 'witch hunt' on the part of the HET is to see that it is not simply a rational weighing of the evidence, but rather that it is an emotional reaction which is intimately bound up with the politics of loss and loyalty.

During the second phase of the research in 2015, the issue of 'On the Runs' (OTRs) - persons outside Northern Ireland who either would, or fear they would face arrest and prosecution for conflict related offences if they return was of significant concern to interviewees and exacerbated the sense of a biased and impartial approach to the past. In February 2014, following the collapse of a case against IRA Hyde Park bomber John Downey, it became apparent that 187 OTRs had received official 'letters of comfort' from the British government between 2000 and 2012 assuring them that they would not face arrest and prosecution for past crimes. All recipients were republicans and thus, for many loyalists and unionists, the scheme amounted to a secret amnesty negotiated by the former Tony Blair government which

\footnotetext{
${ }^{47}$ Personal interview, UDA, 22 July 2015.

${ }^{48}$ Theodore Kemper, A Social Interactional Theory of Emotions (New York: John Wiley and Sons, 1978).

${ }^{49}$ Personal interview, UDA, 22 July 2015.

${ }^{50}$ George Hamilton, 'PUP Conference Panel on Dealing with the Past: Chief Constable Opening Remarks', 10 October 2015, copy on file with author.

${ }^{51}$ Committee on the Administration of Justice, The Apparatus of Impunity? Human rights violations and the Northern Ireland conflict (Belfast: Committee on the Administration of Justice, 2015).
} 
was determined to keep Republicans on board whatever the cost. While a subsequent judgeled review (the Hallett Review) found the scheme to be lawful and that it did not amount to an amnesty, this did little to assuage Loyalists. ${ }^{52}$ In addition, a number of loyalists have consistently argued that in 1998, the former Northern Ireland Secretary of State Mo Mowlam offered assurances that they would not be pursued for pre-1998 offences. ${ }^{53}$ The disjuncture between loyalists' experiences of legacy investigations - both real and perceived and the existence of the OTR scheme has resulted in a profound sense of anger and humiliation and has reinforced the perception, as one former member of the UDA bluntly put it, that 'them fuckers [republicans] have already had their [the past] dealt with and we are being hounded'. ${ }^{4}$ The resulting belief is that a formal truth process, will, for loyalists, be 'same old same old, ground hog day'. ${ }^{55}$

\section{Loyalty, Blame and Managing Shame}

Closely related to the above theme of betrayal are loyalists' concerns that they would be 'blamed' for the conflict and 'shamed' as a result of their violent pasts - both by the British state and by Republican's seeking to justify their own past. One immediate curiosity is that a statistical breakdown of all conflict related deaths in Northern Ireland demonstrates that, formally, republican paramilitaries were directly responsible for $60 \%$ of deaths, loyalist paramilitaries $30 \%$ and state forces $10 \% .{ }^{56}$ Given such figures, ostensibly at least, republicans, including senior figures now in government in Northern Ireland, have the most to lose from an examination of the past. Yet, throughout the fieldwork stage of this research, the provision of hard data and laying out of such empirical facts had little impact on interviewees' assessment of truth recovery. The following discussion teases out this ambiguity in the loyalist position.

To begin to explain loyalists' concerns, an examination of blame and shame in transitional justice is helpful at this juncture. According to McEvoy and McConnachie, there are three overlapping themes that relate to blame in transitional contexts. One is the power of the "urge to blame'; second is the relationship between blame and punishment; and third is the individualization of responsibility for violence onto only those directly responsible for violent acts. ${ }^{57}$ Given the hurt and pain that results from conflict, the drive to blame is understandable. So too with the allocation of shame. Functioning as a signal of threat to the social bond, shame carries a sense of isolation and stigmatization and its negative consequences include feelings of humiliation, denunciation and unworthiness. ${ }^{58}$ Again, while the emotional desire to shame may be understandable, and not to undermine the individual or collective experience of loss and victimisation, neither will contribute to the restoration of peace or functional social and political relations. Rather, blame and shame confirm polarized political positions, create and reinforce hierarchies of victimhood and fail to recognise the broader context in which violence takes place.

One influential response to the negative consequences of blame and shame is Braithwaite's work on 'reintegrative shaming' whereby shame is reimagined as a positive and important part of the process of social reconciliation after social harm or personal or communal conflict.

\footnotetext{
${ }^{52}$ Heather Hallett, The Report of the Hallett Review: An Independent Review into the On the Runs Administrative Scheme (London: Her Majesty's Stationery Office, 2014).

${ }^{53}$ Belfast Telegraph, 'Mo Mowlam loyalist terror amnesty claim', Belfast Telegraph, 23 March 2010. There is no official confirmation that such a deal was made.

${ }^{54}$ Personal interview, UDA, 22 July 2015.

${ }^{55}$ Personal interview, UVF, 22 July 2015.

${ }^{56}$ Committee on the Administration of Justice, supra $\mathrm{n} 51$.

${ }^{57}$ Kieran McEvoy and Kirsten McConnachie 'Victims and Transitional Justice: Voice, Agency and Blame', Social and Legal Studies 22(4) (2013): 489-513.

${ }^{58}$ See for example: Thomas Scheff and Suzanne Retzinger, Emotions and Violence: Shame and Rage in Destructive Conflicts (Lexington: iUniverse, 2001).
} 
Informing restorative approaches to peace making, re-integrative shaming aims to provide the conditions under which offenders can take ownership of their past acts, but do so in a supportive environment that promotes connection and re-integration with their community. ${ }^{59}$ Truth commissions, particularly following the example of the SATRC often have a strong restorative ethos, whereby truth is thought to be healing and knowledge of culpability a way of handling problematic memories. Yet, interviews with loyalist ex-combatants suggest problems for the utility of the shame-guilt re-integrative paradigm in Northern Ireland. This, as Brewer ${ }^{60}$ argues is because of all post violence emotions, shame-guilt is the one most likely to be used to score political points due to its moral tenor and capacity to translate into the allocation of blame. Particularly acute amongst loyalist ex-combatants is a sense that they have been stigmatized by unionist political elites due to their past actions and prison experience and have experienced feelings of dismissal and intolerance as regards efforts at conflict transformation - 'the state and particularly mainstream unionism have seen me as nothing more than dirt on their shoe because of my actions within the conflict' ${ }^{61}$ Put simply, many feel that a truth process would focus exclusively on acts of violence and for example, fail to recognise the complex reasons why former combatants joined paramilitary groups (often because of intense levels of victimisation within their own community), undermine their own experiences of victimhood and marginalization and compound feelings of defeat, humiliation, fear and anxiety experienced during and post conflict.

From this perspective, and fulfilling Tilly's ${ }^{62}$ critique that truth commissions are designed 'to draw a line between worthy and unworthy citizens', the establishment of a formal truth process offers loyalists little comfort regarding the allocation of blame and shame. One interviewee offered the following blunt assessment: 'it is going to allow unionists to say 'it was them bad boys, it wasn't us'. ${ }^{63}$ The result is that 'there is no appetite to engage with mechanisms such as truth recovery at this time'. ${ }^{64}$ This is not to suggest that loyalists have shied away from acknowledging their role in the conflict or have not engaged in local interventions and discussions around dealing with the past. As many interviewees were keen to emphasise, the loyalist ceasefire statement in 1994 stressed 'abject and true remorse', while an earlier UPRG document reflected 'There is no section of this divided Ulster community which is totally innocent or indeed totally guilty, totally right or totally wrong'. ${ }^{65}$ Their concern however, is captured by Elster ${ }^{66}$ : 'The paradox of shame is that it involves taking a single unworthy action or characteristic to be the whole of a persons identity'. In such a context, loyalists fear a truth process would not foster re-integrative shaming 'that treats a person as a good person who has done a bad thing' but would promote stigmatizing or humiliating shame 'that treats the person as bad' and 'permanently ruptures social bonds' ${ }^{67}$ The question of why loyalists would participate was therefore raised - 'In terms of being an ex-prisoner myself, there is no incentive that anybody could offer me to go and publicly disclose what I was involved in... if someone offered me the lottery to do it, I just wouldn't do it' $^{68}$

\footnotetext{
${ }^{59}$ John Braithwaite, "Learning to Scale up Restorative Justice" in Restorative Justice in Transitional Settings, ed Kerry Clamp (Abingdon: Routledge, 2016), 173-189.

${ }^{60}$ John Brewer, "Dealing with Emotions in Peacemaking" in Emotions, Crime and Justice, eds Susanne Karstedt, Ian Loader and Heather Strang (London: Hart Publishing Ltd, 2011) 295-316.

${ }^{61}$ Shirlow, supra n 22; Personal interview, UVF, 22 July 2015.

${ }^{62}$ Charles Tilly, Credit and Blame (Princeton, New Jersey: Princeton University Press, 2008), 11.

${ }^{63}$ Personal interview, UDA (B), 18 June 2009.

${ }^{64}$ EPIC 2014, supra $n 5$ at 7.

${ }^{65}$ Ulster Political Research Group, Common Sense. Northern Ireland - An Agreed Process (Belfast: Ulster Political Research Group, 1987); CLMC, supra n 6.

${ }^{66}$ Jon Elster, Closing the Books: Transitional Justice in Historical Perspective (Cambridge: Cambridge University Press, 2004).

${ }^{67}$ Braithwaite, supra n 12.

${ }^{68}$ Personal interview, UVF, 28 April 2009.
} 
Moreover, to unlock reintegration and restoration, the expression of shame-guilt needs to be heard as 'true' and 'genuine' by one's opponent. ${ }^{69}$ One problem was repeatedly raised by participants - the capacity or willingness of republican politicians and ex-combatants to engage with a truth process in a way loyalist's considered full and satisfactory. This concern is linked to long-standing opposition to what loyalists regard as Republican attempts to manipulate history through sanitizing the Provisional IRA's campaign and portraying loyalists as criminals and at the whim at the British state, rather than individuals who were active agents in their own right. In addition to issues of trust, a significant number of interviewees attempted to link the 'military' nature of their campaign and the 'individual' nature of Protestant culture to a greater honesty over their past actions and compared this unfavorably with republican's 'political' campaign and more collective political culture. The following quotations by former affiliates of the UDA best capture this mentality:

Within the circles that I grew up in and worked in and still do, a lot of people talk from 'I', they are taking responsibility for their actions, they are not looking to blame anybody else, they are not looking for the justifications, the reasons, the excuses why...Sinn Fein and the Provisional movement talk from the corporate. It's like 'hands off, it wasn't really us, it was this body that is out there that did things' ${ }^{70}$

There is a different ethos in the Protestant community, murder is murder, it is wrong, the UDA, UVF or whatever, no doubt they knew it was wrong before they went out and did it, whereas the Catholic side, there is all the psychology - it isn't a human being you are killing, it's a uniform - what a load of bollocks. ${ }^{71}$

Given the widely accepted unwillingness of individual former combatants to provide full disclosure of their past offences in Northern Ireland, one of the much discussed options in the jurisdiction is some form of 'corporate approach' to the past. ${ }^{72}$ This is certainly the approach favoured by one of the key loyalist groupings, the UVF. ${ }^{73}$ However, the above quotations demonstrate that the association between truth recovery, blame, shame and re-integrative shaming does not adequately respond to the emotional dynamics of loyalist paramilitarism in post conflict Northern Ireland. Interviewees expressed a willingness to respond to victims' needs and as noted above, the broader project of 'dealing with the past'. A relationship between loyalty, honour and honesty frequently structured their responses and may be thought of as part of the trinity of rights, responsibilities and obligations that Grodzins ${ }^{74}$ argues is inherent to loyalty. The flipside to this commitment to honesty is that loyalists feel they would be left open to blame and stigmatizing shame by unionist politicians and Republicans, who many felt would use a collective approach to truth recovery as a mechanism through which to evade issues from their own pasts. In this context, loyalists fear that formal truth recovery may readily translate into scapegoating and a narrowing of the capacity for critical contestation and deliberation on the past more broadly.

\section{Loyalty as Silence: A Pro-State Problem}

The third manifestation of loyalty is the notion of 'loyalty as silence'. This form of silence stems from the unconditional commitment and perseverance that is intrinsic to true loyalty, as

\footnotetext{
${ }^{69}$ Brewer, supra n 60.

${ }^{70}$ Personal interview, UDA, 22 July 2015.

${ }^{71}$ Personal interview, UDA, 11 June 2009.

${ }^{72}$ Brian Rowan, Unfinished Peace: Thoughts on Northern Ireland's Unanswered Past (Newtownards: Colourpoint Books, 2015).

${ }^{73}$ EPIC 2014, supra n 5.

${ }^{74}$ Morton Grodzins, The Loyal and the Disloyal: Social Boundaries of Patriotism and Treason

(Cleveland: Meridian Books, 1956).
} 
according to Lamb ${ }^{75}$, 'Loyalty to group does not simply presume that the group is right, but that they care about the right things and make their judgments, even when they are mistaken, in terms of those shared values'. Hochschild ${ }^{76}$ has famously argued that the display, management and performance of emotions are governed by 'display rules' which regulate which emotions should and should not be performed publicly and their depth and extent. 'Deep emotions' (what one really feels) may subsequently not be acted out publicly in preference to the performance of 'surface emotions' (the emotions one seems to be feeling based on one's behavior). ${ }^{77}$ Loyalty therefore poses particular challenges for emotional labour, as, by definition, group members should act with partiality towards those to whom they are loyal. ${ }^{78}$ Yet, it is inevitable that emotions experienced as an individual will conflict with group emotions, the acting out of which is to be disloyal.

For many loyalist interviewees, the need to remain 'loyal' to the British state and prove their identity as 'loyalists' posed a challenge to their willingness to support or participate in a truth process. Two overlapping dynamics can be identified. First concerns the mechanics of truth recovery itself. While there are real dangers in creating a kind of moral relativism which seeks to negate individual or structural responsibility for wrongdoing, a full appreciation of the past necessitates capturing individual human agency and hurt as well as the broader causes, context and consequences within which violent acts occurred. The participation of all parties to the conflict is therefore imperative. In Northern Ireland, this includes the British state. However, for the majority of interviewees, to engage in an initiative which would challenge the state's narrative of the conflict and expose problematic practices was profoundly challenging - 'It is our state...it would be anti-state, it would be against everything that we stand for'. ${ }^{79}$

This is not to say that interviewees were uncritical of the role of the state during the conflict, or of the potential value of interrogating their relationship with the State. One former member of the UVF was extremely clear on this point - '...challenging the state to me isn't an issue because, you know, the state arrested me, they incarcerated me, they abused me and so on and so forth, so I personally don't have any issues with challenging the state ${ }^{80}$ Moreover, the ambiguity of their relationship with the State was not lost on one UDA associated interviewee

...one of the things a lot of them discuss is when they ended up in jail, and the person locking the door has the Queen's crown on his head and I'm looking at it and going, 'what, I'm fighting for you and you are locking me up'. So there is that aspect, the 'what the fuck, what is that about' - but they were loyal. ${ }^{81}$

This quotation captures what Hochschild ${ }^{82}$ calls the "moment of "pinch" - the discrepancy between what one does feel and what one wants to feel. As is also illustrated, loyalty is the subject of strict emotion management as personal feelings of anger, shame and humiliation are subordinated to the performance of group loyalty. For Erwin ${ }^{83}$, this capacity to decouple the public performance of emotions from how emotions are played out in private is a marker of a 'really loyal person'. Loyalists' loyalty to the state has therefore demanded 'emotion

\footnotetext{
${ }^{75}$ Michele Lamb, 'Loyalty and human rights: liminality and social action in a divided society', The International Journal of Human Rights 14(6) (2010): 999

${ }^{76}$ Arlie Hochschild, 'Emotion Work, Feeling Rules and Social Structure', American Journal of Sociology 85(3) (1979): 551-575.

${ }^{77}$ Arlie Hochschild, The Managed Heart: Commercialization of Human Feeling (London: University of California Press, 2012).

${ }^{78}$ Lamb, supra n 75

${ }^{79}$ Personal interview, UDA (B), 18 June 2009.

${ }^{80}$ Personal interview, UVF, 22 July 2015.

${ }^{81}$ Personal interview, UDA, 22 July 2015.

${ }^{82}$ Hochschild, supra $\mathrm{n} 76$ at 562

${ }^{83}$ R Ewin, 'Loyalty and the Virtues', The Philosophical Quarterly 42(169) (1992): 405
} 
work' from ex-combatants - an artful construction of emotions between their 'front' and 'back' stage selves. ${ }^{84}$ The existence of a truth process would surely further, if not strain, this demand.

Second, implicit amongst interviewees was a desire to differentiate themselves from nationalists and republicans on the basis of loyalty or disloyalty. Loyalty as silence may therefore be a strategic necessity. For Fletcher ${ }^{85}$, it is 'membership in a group competing with other groups' which is the hallmark of loyalty. Described in classic terms by Said, these processes of inclusion and exclusion involve the definition of the Other as not just different, but also as inferior; the disloyal and dangerous enemy. ${ }^{86}$ To maintain their identity as 'loyalists' and supporters of the State, loyalists need to 'work within the role', meaning that to question or criticize the state has been interpreted as an indicator of disloyalty more readily associated with nationalists and republicans. Being loyal has therefore demanded the preservation of binary oppositions between 'them' and 'us' at times to the neglect of hurt, loss and grievances amongst loyalist ex-combatants. Equally, for some interviewees, to call for repeated investigations of the past was interpreted as breaking the conventions of military loyalty or diluting the 'warriors honour'. ${ }^{87}$ The somewhat scathing attitude of one interviewee to republican's calls for legacy investigations typifies this point:

I have had friends who were killed by members of the security forces under more than suspicious circumstances and we don't call for inquiries. Our view on it is you are involved in a dirty old business, if you can't stand the heat get out of the kitchen. ... from a Protestant point of view we are not used to gurning, big boy's don't cry. ${ }^{88}$

Two points stand out. Borne out of a defensive mentality, there was a sense among certain interviewees that 'war is war' and that combatants should not only be ready to accept the consequences of violent conflict, but also that maintaining silence on past transgressions and discomforts is the socially expected response. Existing or prospective mechanisms of truth recovery may therefore be thought of as 'rule reminders' for loyalist ex-combatants, whereby in light of a potential examination of past actions and inactions, grievances and discomforts are relegated to the private sphere, and the public voice is one of loyalty, support and commitment to the state. ${ }^{89}$

\section{Loyalty as Protection: Truth as Trauma and Moving On}

The final area this paper addresses is the emotional legacy of the combatant experience. Its starting point is the argument that 'The past is the past, that episode is over and let's get on with the future' ${ }^{90}$ Given that many interviewees qualified their remarks with reference to the potential for a truth process to retraumatise individuals and communities affected by the conflict, this approach can be conceptualized as one of 'loyalty as protection' - the decision to remain silent as a way to guard against revisiting a traumatic past. The tenor of this discussion is in direct contrast to the portrayal of truth telling as a forum for the airing, management and discharging of deep emotions and in the case of South Africa, the transformation of private pain into public shame. ${ }^{91}$ Equally, it poses a challenge to the thesis

\footnotetext{
${ }^{84}$ Erving Goffman, The Presentation of Self in Everyday Life (Harmondsworth: Penguin, 1959); Hochschild, supra $\mathrm{n} 76$.

${ }^{85}$ George Fletcher, Loyalty: An Essay on the Morality of Relationships (New York: Oxford University Press, 1993).

${ }^{86}$ Edward Said, Orientalism (London: Penguin, 2003).

${ }^{87}$ Michael Ignatieff, The Warrior's Honour: Ethnic War and the Modern Conscience (New York: Henry Holt \& Co, 1998).

${ }^{88}$ Personal interview, UDA (B), 18 June 2009.

${ }^{89}$ Hochschild, supra $\mathrm{n} 77$.

${ }^{90}$ Personal interview, UDA (B), 18 June 2009.

${ }^{91}$ See for example: Tutu supra $n 10$.
} 
that participation in truth recovery can aid the re-integration of ex-combatants. Rather, in the discussion below, I will argue that loyalists' attempts to manage traumatic emotions has two distinct manifestations at the micro and macro sociological levels - protection of the self and others, and protection of the peace.

That Northern Ireland has one of the highest rates of male suicide in Western Europe, a prescription rate for anti-depressants that is one of the highest in the world and growing evidence of transgenerational trauma suggests that it is a society that is far from managing the emotional legacy of conflict. ${ }^{92}$ Loyalist ex-combatants were keenly attuned to these difficulties. In many cases, their anxieties were borne out of practical experience and speak directly to the more critical transitional justice literature on the oversimplified association between 'revealing' and 'healing,. can't cope with what they done, with what happened and they don't want to revisit it'. ${ }^{94}$ Second was a narrative on the experience of one loyalist ex-combatant who, after attending a course on the recognition of trauma in South Africa, took his own life on returning home 'basically because it had opened that whole can of worms in his head...That was trauma training... so what is going to happen to someone who gets hit with the truth? ${ }^{95}$

The picture painted by interviewees was one where a complex interplay of negative emotions including the mourning of lost friends and family members, guilt, fear, regret and humiliation experienced during interrogation and imprisonment exerted a considerable hold over former combatants. This assessment is further evidenced by Jamieson, Shirlow and Grounds ${ }^{9}, 6$ research with former politically motivated prisoners which found that amongst loyalist excombatants, $38.4 \%$ reported feelings of despair and not wanting to go on living, $53.3 \%$ experienced intrusive memories and $65.8 \%$ used avoidance techniques as a coping mechanism. Emotion management is firmly in the private sphere and amongst loyalist excombatants has manifested in hazardous levels of alcohol abuse and a prevalence rate for sedative or tranquilliser use that is five times higher than the Northern Ireland average for men. ${ }^{97}$ For those who do chose to articulate their emotions, it is often in the most hidden and emotionally challenging of circumstances. One interviewee for example recounted late night conversations with other ex-combatants in which '...they offload quite a lot. ...Then I am sitting there at 4 o'clock [in the morning] going 'where do I go with that', but I wouldn't turn anybody away'. ${ }^{98}$ In such circumstances, emotional trauma is 'managed' within the group and at the micro sociological level, trauma, loss and fear of the past have translated into a form of protective loyalty that is orientated towards protecting the self and others from further emotional damage.

At the macro sociological level, the public-private display of emotions is also closely mediated and directed towards the maintenance of peace and stability. As detailed above, the majority of interviewees were closely involved in local conflict transformation initiatives. Indeed, it has been argued that their skills and abilities derived from past experiences, prison time and for some, involvement in local politics have been central to defusing local cultures

\footnotetext{
${ }^{92}$ Mike Tomlinson, 'War, peace and suicide: The case of Northern Ireland', International Sociology 27(4) (2012): 464-482.

${ }^{93}$ See for example: David Mendeloff, 'Truth-Seeking, Truth-Telling, and Post-Conflict Peacebuilding: Curb the Enthusiasm?', International Studies Review 6(3) (2004): 355-380.

${ }^{94}$ Personal interview, UDA, 24 June 2009.

${ }^{95}$ Personal interview, UDA (B), 18 June 2009.

${ }^{96}$ Ruth Jamieson, Pete Shirlow and Adrian Grounds, Aging and social exclusion among former politically motivated prisoners in Northern Ireland and the border region of Ireland (Belfast: Community Foundation Northern Ireland, 2010).

${ }^{97}$ Ibid.

${ }^{98}$ Personal interview, UDA, 22 July 2015.
} 
of violence. ${ }^{99}$ Many interviewees spoke passionately and proudly about their involvement in such schemes, often presenting their peacetime roles as a public duty, the flipside to the expression of loyalty that led to their original involvement in conflict. Evidence that conflict transformation work is a way of 'making good' or atoning for past actions has also been presented by Brewer, Mitchell and Leavey. ${ }^{100}$ That interviewees frequently claimed their 'role' is to dissuade younger generations of the efficacy of violence by detailing their prison experience in the starkest of terms fits firmly with this thesis. As Brewer et $\mathrm{al}^{101}$ suggest, such practices may also be a conscious or unconscious attempt to alleviate unresolved guilt without needing to come to terms with one's own past.

Yet, this emotional commitment to conflict transformation was frequently coupled with a ready acknowledgment that dealing with the past could easily tip fragile communities back into conflict. Brewer suggests that this may be particularly the case in societies like Northern Ireland where victimhood is diffuse and contested or where the transitional jurisdiction is a 'small society' with close-knit communities and a high local impact of violence. ${ }^{102}$ One interviewee honed in on this point - 'where we live it is going to be someone across the road coming and saying I planned to kill your wife and daughter. I just don't want to know' ${ }^{103}$ In other instances and reflecting Ignatieff's ${ }^{104}$ argument that revenge is part of the desire to keep faith with the dead and to honour their memory, the prospect of retaliatory violence was starkly stated:

It only takes one to say 'is that right? I'm going to kill them' once they know who that is. This is only a wee small country, you only have to get on a bus to go and kill somebody and that is scary. ${ }^{105}$

This statement illustrates the concern that rather than dissipating emotional tensions, a truth process could inflame negative emotions of anger, hatred, rage and humiliation. Moreover, Brewer argues that dealing with the past is, by nature, backward looking.$^{106}$ By maintaining a backward glance and, if cultures of violence were reignited, socially productive practices such as cross community initiatives, reconciliation projects and broader peace-building work could become subsumed by discussions on the morality of the past or the consequences of renewed violence. ${ }^{107}$ One former member of the UVF, now engaged in cross-community work pointed to the difficulties of maintaining his own role and focus in such a context -

I know that if I am sitting with a guy who I know tried to kill my wife and daughter, that changes things. For anyone to say that it wouldn't change things - they are living in cloud cuckoo-land.... you can't tell me that these relationships would not be different. ${ }^{108}$

A reluctance to engage in truth telling may therefore not only be an attempt to protect communities from the consequences of violence, but also to protect the space in which socially productive practices and behaviours can be maintained and developed. ${ }^{109}$

\footnotetext{
${ }^{99}$ Kieran McEvoy and Pete Shirlow, 'Re-imagining DDR. Ex-Combatants, leadership and moral agency in conflict transformation', Theoretical Criminology 13(1) (2009): 31-59.

${ }^{100}$ John Brewer, David Mitchell and Gerard Leavey, Ex-Combatants, Religion and Peace in Northern Ireland (Hampshire: Palgrave Macmillan, 2013).

${ }^{101}$ Ibid.

102 John Brewer, Peace Processes: A Sociological Approach (London: Polity, 2010).

${ }^{103}$ Personal interview, UDA (B), 18 June 2009.

${ }^{104}$ Ignatieff, supra n 87.

${ }^{105}$ Personal interview, UDA, 11 June 2009.

${ }^{106}$ Brewer supra $\mathrm{n} 11$.

${ }^{107}$ Ibid.

${ }^{108}$ Personal interview, UDA (B), 18 June 2009.

${ }^{109}$ Brewer, supra n 102.
} 


\section{Conclusion}

Focusing on the attitudes, behaviours and actions of loyalist pro-state ex-combatants, this paper has traced how loyalty has impacted upon their attitudes to dealing with the legacy of the Northern Ireland conflict. It is not the case that loyalist ex-combatants are simply 'opposed' to dealing with the past. Rather, many have and want to play a role in conflict transformation initiatives and truth recovery in specific. The framework of formal truth recovery is not, however, as yet, equipped to deal with the demands, obligations and anxieties that loyalty exerts and the confidence and trust that need to be developed. As this paper has demonstrated, loyalist's deeply emotional response is bound up with politics and ideology and, despite objective facts, has translated into a perception that truth recovery is imbalanced and weighted against loyalists, that they will be 'blamed' and 'shamed' for their role in the conflict, that they cannot speak of the past without betraying their loyal identity and that truth recovery would retraumatise ex-combatants and their communities. Hence, loyalists remain at some distance from this debate and feel unable to engage with it on their own terms.

Advancing a more complex notion of loyalty, this paper contributes to the evolution of the debate on truth recovery in Northern Ireland and the field of transitional justice more widely. As regards Northern Ireland, the jurisdiction is at a critical juncture in its efforts to deal with the legacy of the conflict. This paper demonstrates that a greater appreciation of the role of emotions, and specifically, a concerted to attempt to broaden the conversation away from emotions such as anger or revenge, to include loyalty is essential to securing loyalist excombatants' confidence and trust in any prospective mechanisms of truth recovery. Loyalist ex-combatants' loyalty has both an identity dimension and a practical, indeed violent, manifestation. Moreover, that loyalty is mediated through the lens of the past, the present and the future and the individual and the group. Without a more nuanced appreciation of their emotional response to the conflict, its legacy and legacy mechanisms, not only will loyalist ex-combatants experience further fear and alienation from legacy processes, but the benefits of their contribution to truth recovery initiatives - both for ex-combatants themselves and for victims will not be realized.

More broadly, developments in the theory and practice of transitional justice have tended to reward the expression of certain types of emotion - the dominance of forgiveness, the expression of guilt, the diminution of feelings of anger or expressions of revenge and, as Flam suggests, have created (implicit) emotional rule regimes - the pressure to act as a forgiving victim or a repentant perpetrator for example. ${ }^{110}$ As regards loyalty, this style of emotion management fails to appreciate how ex-combatants' loyalty to the past, the present and the future shapes their attitudes to transitional justice and their willingness to participate in truth recovery mechanisms. Ultimately, the emotional landscape of post conflict societies is simplified and reduced and the space in which the past is dealt with is narrowed. Drawing attention to the emotional challenges posed by loyalty in a post-conflict context, this paper begins to expand that debate.

\footnotetext{
${ }^{110}$ Helena Flam, 'The transnational movement for Truth, Justice and Reconciliation as an emotional (rule) regime?' Journal of Political Power 6(3) (2013): 363-383.
} 